\title{
A ESCRITA DA PESQUISA: uma conversa a partir de Freud, Lacan e Foucault
}

\author{
Simone Zanon Moschen \\ Universidade Federal do Rio Grande do Sul - UFRGS, Brasil \\ Jorge Manuel Nunes Ramos do Ó \\ Universidade de Lisboa - ULisboa, Portugal
}

\begin{abstract}
Resumo
Partindo da convocação para pensar o problema da escrita da pesquisa, o artigo sustenta o escrever como uma prática de si, como um processo de invenção cujos efeitos redundam sobre o texto, sobre o objeto que ele contorna, sobre quem segura a pena e, ainda, sobre o endereço que ele mira. Tratase de um processo em que o autor não é suposto na origem da escrita, nem mesmo está, em relação a esta, num lugar de completo domínio; ao contrário, a posição do investigador e as proposições da pesquisa decantam do próprio percurso do texto, como resultante - e não resultado - dos impasses do pensamento, das idas e vindas de sua elaboração, do entrecruzamento de muitas vozes em sua palavra. O presente artigo sustenta suas proposições em uma conversa na qual se fazem presentes Freud, Lacan e Foucault, numa trama em que proximidades e distâncias se tecem articulando as condições para qualificar as perguntas que emergem da prática da escrita da pesquisa sustentada nas trocas que têm lugar na pequena comunidade que o grupo de orientação representa.
\end{abstract}

Palavras-chave: Escrita acadêmica; Arte de existir; Psicanálise; Foucault; Freud; Lacan.

\begin{abstract}
Starting from the call to think the issue of research writing, the paper claims the writing as a practice of the self, as an invention process whose effects have an impact on the text, on the object contained by it, on the one who holds the pen, as well as on the address targeted by him. It is a process in which the author is not assumed in the origin of the writing, he is not even in a place of full mastering of the writing. On the opposite, the position of the researcher and the research proposals decant from the very course of the text, as a resulting - and not result - of the impasses of the thought, the coming and going of its development, the intersection of many voices in its word. This article grounds its proposals on a conversation in which Freud, Lacan, and Foucault are present, in a weave in which closeness and distancing are weaved when articulating the conditions to qualify the questions that emerge from the practice of the research writing supported by the exchanges that happen in the small community represented by the advising group.
\end{abstract}

Keywords: Academic writing; Art of existing; Psychoanalysis; Foucault; Freud; Lacan. 


\section{Para abrir a conversa}

O presente artigo registra uma conversa em torno do tema da escrita da pesquisa a partir de duas perspectivas desse problema: a psicanálise de Freud e Lacan e a filosofia da diferença em Foucault. Ainda que o colóquio se dê em português, as sutilezas dessa língua enunciada em territórios separados por um oceano - Brasil e Portugal - evidenciam tanto diferenças quanto semelhanças nas perspectivas que a temática, mobilizada por esses autores, abre. São aproximações e distâncias que acabam por se escreverem em uma língua que é a mesma sem deixar de ser outra.

Partindo da instigação a pensar o problema da escrita da pesquisa, que decanta de um longo percurso de acompanhamento da elaboração de dissertações e teses no seio de uma comunidade de pesquisa, conhecida, frequentemente, como grupo de orientação, o artigo sustenta o escrever como uma prática de si, como um processo de invenção cujos efeitos redundam sobre o texto, sobre o objeto que ele contorna, sobre quem segura a pena e sobre o seu endereçamento. Trata-se de um processo em que o autor não é suposto origem da escrita, nem mesmo está em relação a esta em uma posição de completo domínio; ao contrário, ele decanta do percurso do texto, como resultante - e não resultado - dos impasses do pensamento, das idas e vindas de sua elaboração, do entrecruzamento de muitas vozes em sua palavra.

Essa tomada de posição perante a escrita da pesquisa implica a defesa de uma zona de liberdade capaz de acolher as inquietações que emergem nos caminhos das investigações. Uma liberdade que se faz acompanhar por um exercício consequente de responsabilidade, na medida em que, se o que se escreve não espelha um mundo que existiria antes mesmo do gesto de escrever e que esse gesto não faria mais do que revelá-lo, o que redunda da escrita da pesquisa como nomeação, ou ainda, como indicação de um porvir, demanda a responsabilidade de quem a enuncia. Embora não estejamos no controle do que escrevemos, somos responsáveis pelo que elaboramos e pelo mundo que sobrevém a essa nomeação. É no trânsito por esse paradoxo que este artigo busca em autores como Freud, Lacan e Foucault elementos que possam sustentar a força inventiva - e disruptiva - de que pode se revestir a escrita acadêmica, bem como sua responsabilidade sobre a construção de um mundo mais largo, mais respirável, menos triste. Ao fazê-lo, este texto quer incidir sobre as políticas do texto na academia, abrindo espaço para um pesquisar que sustente as condições da escrita como exercício de uma arte de existir. 


\section{A psicanálise e a escrita da pesquisa}

\subsection{Psicanálise e ficção}

Freud, em 1895, ao iniciar a discussão do caso da Srta. Elisabeth Von R., situa:

Nem sempre fui psicoterapeuta. Como outros neuropatologistas, fui preparado para empregar diagnósticos locais e eletroprognósticos, e ainda me causa estranheza que os relatos de casos que escrevo pareçam contos e que, como se poderia dizer, falta-lhes a marca da seriedade da ciência. Tenho de consolar-me com a reflexão de que a natureza do assunto é evidentemente responsável por isso, e não qualquer preferência minha. (Freud, 1996, p. 172, grifo nosso)

Ao situar a natureza do assunto como diretora da forma que seu texto toma, a pontuação freudiana convoca um pensamento sobre os efeitos do objeto de pesquisa nos contornos que a sua construção escrita assume. Sua indicação, como não poderia deixar de ser, situa o eu que escreve numa posição subordinada - sujeita - ao objeto escrito.

A marca do romance, como estrutura narrativa na qual Freud opera a transmissão de sua clínica, é de tal ordem pregnante que o único prêmio que o pai da psicanálise galgou em vida foi o prêmio Goethe de literatura. Contudo, podemos propor que essa inflexão ao literário se impôs ao autor como um efeito daquilo que o psicanalista procurava transmitir e não esteve presente como uma escolha antecipada ao ato de escrever. O que em sua clínica lhe impôs esse desvio?

A análise é uma experiência de fala descontínua, com idas, vindas e irrupções; uma experiência plasmada em diferentes camadas temporais, articulada pelo a posteriori, mas também pela antecipação; uma experiência em que o abismo entre a enunciação e o enunciado se faz ver nas mais diversas formações do inconsciente - lapsos, sonhos, sintomas, chistes; uma experiência em que as intervenções do analista estilhaçam sentidos fixados, fazendo voar para longe do centro os cacos significantes que, no território em que se assentam, irão compor novos sentidos... Enfim, uma análise é um experiência que não tem como derivar a força de sua transmissão do relato factual do fio discursivo desenrolado na cronologia das sessões. Transmitir a clínica psicanalítica implica haver-se com o desafio de fisgar, na sequência das palavras, uma força disruptiva que acaba, paradoxalmente, por localizar o limite que atravessa toda vontade de transmissão. Um relato linear não teria como dar lugar aos efeitos de verdade que se produzem durante uma análise. É preciso alcançar outra forma de contar.

Os desafios de transmitir um conhecimento oriundo de um território experiencial não é privilégio da clínica psicanalítica, ele também se conjuga nos mais diversos campos em que a matéria do pensamento - e do acontecimento - é a própria linguagem matizada pelas aberturas que a polissemia que lhe é característica inscreve. Retomar alguns elementos que nos chegam da história da psicanálise talvez possa nos fazer avançar naquilo que se conjuga 
como um desafio à escrita da pesquisa em campos como a educação, a história, a antropologia, as artes...

Um primeiro ponto a levantar são as relações que a psicanálise estabeleceu com a literatura. Freud entreteceu um laço de pensamento importante com a literatura, um laço que reconhecia no texto literário um saber que se cifrava na cultura antes mesmo que o psicanalista pudesse enunciá-lo a partir de seu campo. Se a história nos legou uma série de análises de textos literários que poderíamos caracterizar como violentas, seja por estabelecer uma relação entre o escrito e uma suposta psicopatologia do autor, seja por impor um metatexto psicanalítico à trama que a escrita literária desdobrava; Freud, não raras vezes, ocupou uma posição de (re)conhecer na literatura o enunciado de um drama humano, tal qual ele procurava localizar com sua ciência nascente. Em carta ao escritor Arthur Schnitzler, também médico e vienense, Freud diz reconhecer nele o seu duplo:

Sempre me atormentei com a pergunta sobre a razão por que em todos esses anos nunca procurei conhecê-lo nem conversar com o senhor [...]. A resposta contém a confissão que me parece íntima demais. Acho que evitei o senhor por causa de uma espécie de relutância em conhecer o meu sósia. Não que eu me incline facilmente a identificar-me com outrem, ou que pretenda fazer pouco da diferença de talento que me separa do senhor, mas todas as vezes em que me absorvo profundamente nas suas belas criações pareço sempre encontrar sob uma superfície poética os mesmos pressupostos, interesses e conclusões que alimento. (Freud, 1922, n. p., grifo nosso)

Freud, de algum modo, identifica em Schnitzler seu duplo, reconhece em seu trabalho com a língua, no exercício poético de sua escrita, uma similaridade com o seu fazer. Sua confissão íntima indica a posição mais potente que a psicanálise pode ocupar no laço com a literatura: uma indagação sobre o que o saber-fazer-com-a-linguagem operado pelos escritores pode ensinar aos psicanalistas acerca do que os desafia - na clínica e em sua transmissão. Exemplo potente dessa relação é o trabalho de Freud em torno do texto de E. T. Hoffmann, "O Homem da Areia". Ao se perguntar sobre o que a novela de Hoffmann pensa, Freud abre caminho para um trabalho com as letras do escritor; trabalho que o leva a dar contornos à noção de unheimlich (o infamiliar), tão cara a seu pensamento (Freud, 2019).

Também vale ressaltar que Freud situa a "superfície poética" como o território em que seu fazer e o de Schnitzler se encontram. Situar a função poética da linguagem como um ponto de toque entre o que o psicanalista e o escritor procuram fazer com a língua indica que a função comunicativa da linguagem não ocupa de forma soberana a arena onde se travam as batalhas tanto da psicanálise quanto da literatura. Ao contrário, atentar - ou produzir - o lugar em que a função comunicativa da língua é desativada, colocada à reboque de uma força instauradora capaz de engendrar o novo, é ponto de mira comum à psicanálise e ao exercício literário - ambas as práxis procuram ativar a função poética da linguagem; tramitam, no dizer de Freud, sobre uma "superfície poética".

Michel de Certeau (2011), dá uma volta a mais nos contornos da relação entre psicanálise e literatura. Tomando a transmissão operada na psicanálise como um exercício que guarda 
analogias com o trabalho historiográfico, ele nos lega a preciosa indicação: tal como a matemática se converte na linguagem sobre a qual se assenta a construção do conhecimento nas ciências exatas, a "literatura é o discurso teórico dos processos históricos. Ela cria o não lugar em que as operações efetivas de uma sociedade têm acesso a uma formalização" (Certeau, 2011, p. 92). Indicar a literatura na posição de linguagem em que se conjugam os processos históricos tem como consequência cravar a ficção no coração das indagações acerca da formalização e transmissão de um conhecimento que deriva de uma experiência humana.

Lacan (1997, p. 22), por sua vez, lega-nos como princípio metodológico o aforisma: "toda verdade tem uma estrutura de ficção"; e aqui ficção não toma parte da linha semântica que se desloca na direção do falso ou do enganador; ficção desliza de modo que em algum ponto da cadeia se articula ao simbólico, ao que com a linguagem é possível contornar. "A ficção - sob suas modalidades míticas, literárias, científicas ou metafóricas - é um discurso que dá forma ['informe'] ao real, sem qualquer pretensão de representá-lo ou ser credenciado por ele" (Certeau, 2011, p. 48).

No caminho que nossa retomada indica, aquilo que se escreve como percurso de pesquisa se tece plasmado em uma estrutura ficcional que acaba por contornar um real que se apresenta, a um só tempo, como efeito e causa - a posteriori - da escrita. Efeito, porque do trabalho da escrita podem resultar novas formas de dizer que localizam, a partir de outros prismas, o que em cada dito permanece mudo; causa, porque uma vez nomeada a experiência passa a figurar como tendo estado ali desde sempre e, desde esta anterioridade alcançada no a posteriori do dito, aparece como tendo demandado o trabalho de nomeação que, na verdade, não fez mais do que lhe dar existência. Não é pela busca de finalmente dizer o real que nos movimentamos na escrita da pesquisa, mas pela procura por indicar que cada tentativa de enunciar o humano produz um resto, escreve novos riscos - na polissemia dessa palavra -, novos contornos, ao real que nos sacode.

A psicanálise, com Freud, substitui “o discurso ‘objetivo' (aquele que visa dizer o real) por um discurso que assume a figura de 'ficção' [...]" (Certeau, 2011, p. 75). Ao indicar o lugar que a ficção ocupa na elaboração teórica - lembremos que a psicanálise é adjetivada de "ficção teórica" em A interpretação dos sonhos (1900) -, Freud acaba por indicar, também, que o que se formaliza como conhecimento carrega consigo, inelutavelmente, os limites que um lugar de enunciação impõe. O gesto que faz nascer no coração da escrita da pesquisa psicanalítica a estrutura da ficção é o mesmo que situa como seu incontornável limite - e possibilidade - o lugar enunciativo do pesquisador. Pensamos que uma escrita que não recalca seu lugar de enunciação - e os limites que este lugar impõe - lega aos leitores como herança a falta que lhe engendrou e, dessa forma, convida-os a seguir no trilho de estender as condições de enunciar o humano, ainda que sempre parcialmente.

E para tomar da literatura o que ela pode nos ensinar, lembremos de um famoso conto de Jorge Luís Borges naquilo que ele nos ajuda a pensar sobre a parcialidade como condição da escrita da pesquisa que se debruça sobre um território experiencial. Trata-se de "O Aleph", publicado em 1949, no livro homônimo. Nele, o narrador é levado ao porão de uma casa que está prestes a ser demolida. Ali mora um Aleph, uma pequena esfera furta-cor, de dois ou 
três centímetros, na qual se encontram "sem se confundirem, todos os lugares do orbe, vistos de todos os ângulos” (Borges, 1999, p. 693). Diante de tão absurda experiência, o narrador nos lega seu desespero:

Toda a linguagem é um alfabeto de símbolos cujo exercício pressupõe um passado que os interlocutores compartem; como transmitir aos outros o infinito do Aleph, que minha temerosa memória mal e mal abarca? [...] Mesmo porque o problema central é insolúvel: a enumeração, sequer parcial, de um conjunto infinito. [...] Nesse instante gigantesco vi milhões de atos prazerosos ou atrozes; nenhum me assombrou tanto como o fato de que todos ocupassem o mesmo ponto, sem superposição e sem transparência. $O$ que os meus olhos viram foi simultâneo; $o$ que transcreverei sucessivo, pois a linguagem o é. Algo, entretanto, registrarei. (Borges, 1999, p. 695)

Diante da tarefa de transmitir o Aleph, o narrador se vê num complexo desafio: operar o trânsito, para o registro na escrita, de um espaço sem bordas e de um tempo que não se enfileira pelos ponteiros do relógio. Borges atenta para o fato de que não há como fazer essa passagem sem que algo se perca. No afã de realizar sua empreitada, ele tenta encontrar algo que lhe sirva de analogia, uma ponte que permita a passagem do simultâneo da experiência ao sucessivo de sua narração - travessia na qual ele se precipita ao tentar escrever o que vivenciou. Seus esforços são em vão; não há como operar essa mudança de registros sem perdas. Do simultâneo da imagem ao sucessivo da escrita, da sincronia à diacronia, algo resta. Porém, ainda que diante de um impossível, o protagonista não recua da tarefa do registro; transita nela pelas mãos de uma conjunção adversativa: entretanto!

Das conjunções que estruturam os caminhos da escrita da pesquisa, especialmente quando esta se articula a partir de um campo experiencial, a palavra "entretanto" pode ocupar a posição de um operador metodológico. De algum modo ela localiza os limites implicados em qualquer saber constituído. Limites que se colocam tanto como fruto do próprio operar da linguagem e as aberturas semânticas que ela comporta quanto como efeito da circunscrição própria ao lugar de enunciação que o pesquisador ocupa em determinado momento, constrangido pelos determinantes que seu tempo e seu espaço lhe conferem - como lembrava Maturana (2001, p. 37): "tudo que é dito é dito por um observador a outro observador, que pode ser ele ou ela mesmo" e carrega consigo os contornos que sua posição delimita.

\subsection{Sobre estilo e escrita da pesquisa}

Lacan proferiu seu ensino de forma eminentemente oral. Durante mais de vinte anos manteve seu seminário, um verdadeiro exercício de pensar em companhia. A partir de suas indagações avançava - e retrocedia - na companhia de seu público, exercitando uma fala que queria semelhante à de um analisante; uma fala que comportasse a abertura necessária para o inesperado, para a emergência de um verdadeiro achado. Seu exercício de pensamento no 
território da escrita nos chegou sob a forma de uma compilação de textos publicados em 1966 sob o título de Escritos:

Eu juntei algo que eu tive de chamar Écrits, no plural, porque me pareceu que esse era o termo mais simples para designar o que eu me propus a fazer. Eu juntei sob esse título as coisas que escrevi somente para anotar alguns marcadores, algumas marcas, como os postes que se coloca na água para atracar barcos, em o que eu venho ensinando semanalmente por vinte anos mais ou menos. (Lacan, 2006, p. 60)

Para abrir seus Escritos, Lacan dedica breves páginas a uma discussão sobre o estilo indicando a centralidade que o tema assume em seu pensamento. Seu ponto de partida é a máxima de Buffon: "o estilo é o homem" (Lacan, 1998, p. 9), assertiva que merecerá a sua crítica, renovada ao longo das 900 páginas dessa publicação. Estilo não equivale, em seu pensamento, à localização de qualquer suposta essência que definiria aquele que o atualiza através de cada pequeno gesto. Sua primeira torção na fórmula buffoniana será incluir o endereço como parte daquilo que compõe os contornos de um estilo. "O estilo é o homem; vamos aderir a essa fórmula, somente ao estendê-la: o homem a quem nos endereçamos?" (Lacan, 1998, p. 9). A inclusão do endereçamento como argamassa que estrutura o estilo merece pontuação quando nos perguntamos sobre a escrita que se desdobra no âmbito da pesquisa acadêmica.

Os contornos do canonicamente aceitável, quando se trata de um texto acadêmico, são pontos de negociação para a escrita da pesquisa. Ainda que esta não se aliene aos padrões anestesiantes de uma estrutura pré-formatada, ela precisará se pôr em negociação com aquilo que estrutura essa escrita, sob pena de ser lida como um arroubo desbordante de seu autor. Como refere Barthes ao pensar a leitura, mas, cremos, com ressoos possíveis naquilo que estamos propondo sobre a escrita: "Toda a leitura ocorre no interior de uma estrutura e não no espaço pretensamente livre de uma pretensa espontaneidade: não há 'leitura natural', 'selvagem': a leitura não extravasa da estrutura; fica-lhe submissa; precisa dela, respeita-a mas perverte-a.” (Barthes, 2004, p. 33). A condição que a escrita tem de perverter a estrutura, pensamos, também passa por sua condição de considerá-la.

$\mathrm{O}$ estilo que o texto assume será a resultante desses vetores de força: no eixo das ordenadas, os contornos que o endereço imprime; e no eixo das abscissas, as marcas da resistência - e da insistência - de seu objeto aos modos, a priori formatados, de estruturação do texto, modos que são sustentados e validados pelo seu lugar de endereçamento. Eis a segunda torção proposta por Lacan: o estilo não ressoa do homem nos seus movimentos pela vida, mas do objeto que causa esses movimentos. Nessa medida, o texto, naquilo que dele decanta como estilo, é levado a tomar uma forma e não outra como efeito do objeto que o causa.

É o objeto que responde à pergunta sobre o estilo que formulamos logo de saída. A esse lugar que, para Buffon, era marcado pelo homem, chamamos de queda desse objeto, reveladora por isolá-lo, ao mesmo tempo, como causa do desejo em 
que o sujeito se eclipsa e como suporte do sujeito entre verdade e saber. Queremos, com o percurso de que estes textos são os marcos e com o estilo que seu endereçamento impõe, levar o leitor a uma consequência em que ele precise colocar algo de si. (Lacan, 1998, p. 11).

Importa ressaltar que o objeto na posição de causa do desejo é, para Lacan, não especularizável; não há imagem que lhe seja cabível - ele indica muito mais um vazio do que algo que se positiva por uma imagem. Contudo, em sua condição de não imaginarizável, ele situa-se como motor do trabalho simbólico que se revira sobre si mesmo e que cria, a cada torção, novas formas de dizer, redesenhando, no mesmo gesto, as fronteiras daquilo que lhe é inapreensível. Talvez, num deslocamento um pouco forçado, mas nem por isso menos operante, possamos aproximar os contornos que toma o objeto causa do desejo em Lacan e o trabalho da escrita que dele deriva, da relação que Agamben (2018) estabelece entre o fogo, na posição do mistério, e o relato, como lugar da história que o mistério deixa como rastro. O relato aparece, para Agamben, não como representação do fogo, mas como sua memória; algo do qual não podemos nos aproximar totalmente, sob pena de ardermos em chamas.

Há, porém, um fio, uma espécie de sonda lançada em direção ao mistério, que lhe permite medir a cada vez a distância até o fogo. Essa sonda é a língua, e é na língua que os intervalos e as rupturas que separam o relato e o fogo mostram-se como feridas implacáveis. Os gêneros literários são as chagas que o esquecimento do mistério talha na língua: tragédia, elegia, hino e comédia nada mais são que os modos como a língua chora sua relação perdida com o fogo. (Agamben, 2018, p. $34)$.

Aquele que escreve pode, na escrita, fazer lembrar do fogo que impulsionou esse gesto, ainda que não consiga, com as palavras que emergiram, colocar a arder o papel que as acolhe. O desafio de localizar, na escrita da pesquisa, o lugar a partir do qual nos aproximamos do fogo que nos chama, bem como de testemunhar os rastros que esse chamado deixa, figura a ordem do dia dos que se colocam diante do trabalho de formalizar um conhecimento que emana de um campo experiencial, um campo de linguagem. A inclusão do sujeito - sujeito ao objeto causa de desejo - no trabalho de escrita não deriva de um exercício de autonomia sobre o texto, mas da abertura de espaço para que o objeto que movimenta a pesquisa possa encontrar espaço nas letras. Essa abertura terá como efeito o descentramento do homem de Buffon. Talvez quanto mais homem em um texto, menos espaço para a emergência do sujeito; ou talvez pudéssemos brincar dizendo: a menos objeito ele dê lugar.

Aquilo para o qual Freud atentará muito cedo em sua obra, a saber, os efeitos da natureza do assunto sobre a forma que sua explanação adquire, aparecerá em Lacan, como vimos, como efeito do objeto sobre os modos de transmissão de um saber que decanta de um campo experiencial. Nesse percurso, veremos operar um deslocamento que faz rumar do romance, em Freud, para a poesia, em Lacan; ambos territórios em que os exercícios de linguagem que lhes são próprios fornecem, aos psicanalistas pesquisadores, elementos para contornar o impossível que a transmissão da psicanálise arrasta consigo. Trata-se de uma travessia em 
que a linguagem vai ganhando, cada vez mais, a primazia da cena na transmissão. Como lembra Porge (2009, p. 67), o "estilo é esta dimensão suplementar ao sentido que se liga à maneira de dizer e se faz, por sua vez, suporte de desejo e causa de divisão do sujeito".

Lacan, ao comentar o que lhe chega como dificuldade de alguns de entrar em seu texto, refere:

Lamento, não há nada que eu possa fazer - meu estilo é o que é. [...] sejam quais forem as deficiências de minha lavra que possam aí intervir, há também, nas dificuldades desse estilo, algo que corresponde ao próprio objeto em questão. Uma vez que se trata, com efeito, de falar de maneira válida das funções criadoras que o significante exerce sobre o significado, ou seja, não simplesmente de falar de fala, mas de falar no fio da fala, por assim dizer, para evocar suas próprias funções, talvez haja necessidades internas de estilo que se impõem - a concisão, por exemplo, a alusão, ou até a ironia, que são elementos decisivos para entrar no campo em que as funções da fala dominam não somente as avenidas mas todas a textura. (Lacan, 1999, p. 33, grifos nossos).

Para Lacan, o trabalho teórico da psicanálise se exerce no fio da fala, num equilíbrio precário em que a cada passo o que se diz encontra os limites do dizer; limites que demandam ser incluídos no próprio enunciado. As funções da fala, em Lacan prioritariamente a metáfora e a metonímia, as leis que as articulam, engendram os limites e possibilidades do que pode ser dito; e a construção teórica, além de ser estruturada por esses limites e possibilidades, deverá tomá-los como seu próprio objeto de reflexão. Na escrita da pesquisa que tem na psicanálise seu alicerce, entrará em causa a linguagem não apenas em sua função comunicativa ou informacional, mas especialmente em sua função poética, função que abre espaço a que um estilo emerja - é dessa emergência que se esperam efeitos de transmissão. A palavra que se tece na escrita da pesquisa pode ser tramada de modo a atualizar efeitos que ressoam também na experiência estética do poema ou na experiência analítica da clínica. No presente da escrita da pesquisa pode estar incluída uma pesquisa da escrita em cujo horizonte estaria a produção de uma pesquisa/escrita psicanalítica e não uma pesquisa/escrita sobre a psicanálise.

\subsection{Ensaiar-se na escrita da pesquisa}

Ao retomarmos o trabalho de Max Bense (2014) sobre o ensaio, encontramo-nos com uma forte indicação da presença de uma tessitura entre poesia e prosa. Em sua concepção,

[...] o ensaio é uma peça de realidade em prosa que não perde de vista a poesia. Ensaio significa tentativa. [...] Escreve ensaisticamente quem tenta capturar seu objeto por via experimental, quem descobre ou inventa seu objeto no ato mesmo de escrever, dar forma, comunicar, quem interroga, apalpa, prova, ilumina e aponta tudo o que pode se dar a ver sob as condições manuais e intelectuais do 
autor. O ensaio busca apreender um objeto abstrato ou concreto, literário ou não literário, tal como ele se dá nas condições criadas pela escrita. (Bense, 2014, n. p.).

A articulação inextrincável entre escrita e objeto do ensaio se faz ver na concepção de Bense. A escrita cria condições de possibilidade para a emergência do objeto do ensaio; este, por sua vez, não lhe é anterior, embora figure como sua causa, emergindo como efeito do próprio processo de escrita. A causa, aqui, responde ao a posteriori, tempo afeito às formações do inconsciente - sonhos, lapsos, chistes, sintomas. O ensaio como narrativa é proposto como uma "prosa que não perde de vista a poesia"; uma articulação que comunica, informa, mas também cria sentidos ao tomar também a linguagem como seu objeto.

Starobinski (2011), em seu discurso pronunciado por ocasião do recebimento do Prêmio Europeu do Ensaio, compartilha uma reflexão que, ao prestar homenagem a Montaigne, alerta para o lugar marginal que o ensaio veio a ocupar no âmbito da produção de conhecimento acadêmico: "A Universidade, no apogeu de seu período positivista, tendo fixado as regras e os cânones de pesquisa exaustiva séria, rechaçava o ensaio e o ensaísmo às trevas exteriores, com o risco de banir, no mesmo movimento o brilho do estilo e as audácias do pensamento" (Starobinski, 2011, p. 15). O ensaio, em sua abertura à emergência do sujeito, afronta os ideais de neutralidade de uma ciência positivista. Seu experimentalismo, seu pendor a tramitar na zona de indiscernimento entre prosa e poesia, seu apelo à inclusão do sujeito que o pratica, são elementos que o fazem tensionar o que a academia consagrou como produção científica.

Montaigne faz o ensaio do mundo com suas mãos, com seus sentidos. Mas o mundo lhe resiste, e essa resistência ele deve inapelavelmente percebê-la em seu corpo, no ato da "apreensão". Nesse ato Montaigne sente, decerto, primeiro o objeto, mas, ao mesmo tempo, ele percebe o esforço de sua própria mão. A natureza não está fora de nós, ela nos habita, ela se dá a sentir no prazer e na dor. (Starobinski, 2011, p. 18).

A inclusão de categorias como sentidos, corpo, prazer, dor, na trama que tece e busca transmitir um conhecimento aparece como heresia à neutralidade e à objetividade erigidas como horizonte a perseguir na escrita científica. No ensaio, o mundo se apresenta como resistência a um corpo que busca apreendê-lo e, como tal, não guarda existência anterior ao próprio gesto de apreensão. Há uma tessitura sutil entre o gesto das mãos e o mundo que elas tentam agarrar, e o ensaio surge como documento que registra os movimentos dessa dança. Nessa medida, aquele que ensaia o faz suportado por seu corpo, precisa incluir seu corpo na cena.

Tania Rivera (2017), ao contornar o tema do ensaio e propô-lo como uma forma potente de trabalho do campo psicanalítico, indica que, nessa forma textual, o que está em causa não é uma escrita subjetiva, eventualmente desdobrada em primeira pessoa - o que, muitas vezes, pode até mesmo ser índice de uma inflação egoica no texto, ou ainda, em nossa equação, a presença de muito homem em detrimento de pouco objeito. Starobinski (2011, p. 52) afirma: 
“[...] para satisfazer plenamente à lei do ensaio, convém que o 'ensaísta' ensaie a si mesmo"; sublinhemos: si mesmo. Diríamos, com a autora, que o índice de uma escrita psicanalítica e não sobre a psicanálise - seria a "tomada do si mesmo como experiência" (Rivera, 2017, p. 13).

Rivera (2017), em sua pesquisa sobre o ensaio, leva-nos à passagem latejante de Adorno: "o pensador, na verdade, nem sequer pensa, mas faz de si mesmo o palco da experiência intelectual, sem desemaranhá-la" (Adorno, 2011, p. 30, grifo nosso). Fazer de si mesmo o palco de uma experiência é absolutamente distante da perspectiva de tomar-se como origem de uma narrativa, da atualização de um estilo que emanaria de uma essência que nos é interna. A indicação de Adorno ao estabelecer os contornos do ensaio como forma localiza o exercício do que seria um modo de fazer falar o objeto e dessa falação recolher efeitos de sujeito. De algum modo, o ensaio em seu apelo para que o escrevente se situe como palco de uma experiência intelectual, constitui um espaço de escrita em que o pesquisador pode, mais do que refletir sobre o objeto de sua pesquisa, refletir o objeto; refleti-lo.

[...] vale observar que Montaigne não nos oferece nem um diário íntimo, nem uma autobiografia. Ele se pinta olhando-se no espelho, certamente; mas, com frequência ainda maior, ele se define indiretamente, como se esquecendo de si exprimindo sua opinião: ele se pinta com pinceladas esparsas, a partir de questões de interesse geral: a presunção, a vaidade, o arrependimento, a experiência. (Starobinski, 2011, p. 19).

Tomar a si mesmo como palco de uma experiência que se consuma nesse território de escrita não está em linha de continuidade à confissão de uma intimidade ou à elaboração de uma autobiografia. O ensaísta está no ensaio, mas está como efeito de suas letras, não como origem de sua escrita. Seu trabalho é o de fazer decantar, no registro de suas tentativas de apreender um mundo que lhe resiste, o que desse mundo o forja, o que, proveniente do mundo - de um mundo de linguagem -, dobra-se, através da escrita, para imprimir nele um traço que o singulariza. Um singular que, paradoxalmente, é, antes de mais nada, coletivo. Se o ensaio pode dar guarida à emergência do que estamos chamando de objeito, é porque, salvaguardando o registro da singularidade do ensaísta, sua escrita almeja localizar a impessoalidade dos traços que constituem a experiência que se faz objeto de suas letras; impessoalidade que torna esses traços, também, "questões de interesse geral". De algum modo, localizar a potência da forma ensaio e o que ela pode nos ensinar sobre a pesquisa da escrita é conduzir-se como quem almeja, na escrita da pesquisa, experimentar um espaço de liberdade que possa dar guarida aos ressoos do objeto no texto, fundando, com isso, novas formas de dizer o mundo, de se dizer no mundo, convidando a que a palavra possa sofrer os efeitos do pensamento. 


\section{Foucault e o ofício da pesquisa}

\subsection{A escrita como arte de existir}

Michel Foucault defendeu, ao longo de toda a sua trajetória intelectual e sempre que foi instado a pronunciar-se sobre o assunto, que o ofício da escrita correspondia a uma prática perpétua de desdobramento de si mesmo, e em que os resultados atingidos se deviam tomar como experimentos descritivos destinados a problematizar as evidências incontestadas do presente mas, nunca por nunca, a constituir-se numa lição sobre a vida dos indivíduos. $\mathrm{O}$ gesto da escrita emerge nele tomado de uma dupla radicalidade que ainda nos captura e que aqui queremos invocar: supunha uma entrega sem condição ao seu exercício e, ao mesmo tempo, um combate corpo a corpo a todo e qualquer sinal que a pudesse sacralizar no espaço público. A escrita originalizou-se em Foucault como o nome que se dá à possibilidade, jamais encerrada, de se inventarem novas formas de existência. E também de tomar a palavra no espaço público, que ele mesmo sentia como estando cada vez mais pressionado pelos discursos multiplicados dos pregadores da verdade objetiva e salvadora. Vemo-lo como um legado expressivo e vigorosamente insistente para a afirmação da palavra plural e das intermináveis tarefas da diferenciação que temos pela frente.

O projeto foucaultiano é todo ele atravessado pela consciência de que o saber se constrói inteira e unicamente na ultrapassagem, na transformação e no deslocamento dos problemas já refletidos e ensaiados. Esta espécie de rosca sem fim da palavra escrita supunha que ele negasse com veemência a designação de teórico. O seu caso, como amiúde gostava de sublinhar, não era o de alguém que intentava construir um "sistema global", fosse de "dedução", fosse de "análise", e o aplicava "de maneira uniforme a campos diferentes", mas, ao invés, o de um investigador que se descobria inteiramente mobilizado por um processo de escrita que o levava a "não pensar na mesma coisa que antes". A tal respeito, Michel Foucault gostava de vincar que, quando começava um livro, não entrevia claramente qual a metodologia a ser empregue, admitindo, portanto, que forjava uma análise específica em cada um dos seus diferentes projetos. "Terminado o meu trabalho", confessaria numa entrevista dada em 1978, "posso, por uma espécie de olhar retrospectivo, extrair da experiência que acabo de fazer uma reflexão metodológica que tira o método que o livro pôde seguir". Foi essa dinâmica que o terá levado a escrever em "alternância" livros que denominava de "exploração" - entre outros, os casos de História da loucura (1961) e do Nascimento da clínica (1963) - e também livros de "método", como A arqueologia do saber (1969), aparecidos todos antes de monografias de tipo diferente como Vigiar e punir (1975) e A vontade de saber (1976). A sua atividade reflexiva, entendida como destinada a ajudá-lo a definir "um outro trabalho possível", não se esgotava, no entanto, em produtos como estes. Continuava simultaneamente numa série de outros escritos e intervenções públicas, os quais entrevia e justificava como "espécies de andaimes" que serviam "de relés" entre um trabalho que se estava a acabar e um projeto novo". Mas o importante neste particular estará em reconhecermos que não se tratava, em qualquer dos casos, de estabelecer "um método geral, 
definitivamente válido". Notava a propósito: "o que escrevi não é jamais prescritivo nem para mim nem para os outros; é, quando muito, instrumental e sonhador” (Foucault, 2010b, p. 289-290).

Tome-se como exemplo impressivo a introdução de $A$ arqueologia do saber. Ela foi parcialmente ocupada pela tentativa de estabelecer uma relação com as três obras precedentes, embora Foucault advertisse que o seu novo trabalho não seria, de modo algum, "a retomada e a descrição exata" do que havia defendido antes relativamente às "questões do ser humano, da consciência, da origem e do sujeito". Interessava-lhe então mostrar em muitos pontos que o que então escrevia era diferente e permitia inclusive estabelecer "diversas correções e críticas internas". A posição de que partira levara-o a utilizar conceitos gerais como "experiência", a aproximar-se em várias opções da "análise estrutural" ou a tomar a ausência de limites cronológicos que o haviam aproximado de uma certa "totalidade cultural". O diálogo perpétuo que os seus textos estabeleciam entre si, a espacialidade tão precária e incerta que pareciam delimitar, levavam-no, a cada momento, à certeza de que o seu percurso intelectual consubstanciava uma declinação da identidade. Era imperioso que, antes de tudo o mais, dissesse: "não sou isto e aquilo" (Foucault, 2010a, p. 18-19). Foi para inscrever a possibilidade de uma heteronomia ou de uma ausência de rosto que apresentou nesse texto um diálogo em que ele mesmo respondia a um interlocutor imaginário acerca do sentido da existência sob o impacto do exercício de escrever. Com ele encerrou a apresentação de A arqueologia do saber. Desta forma:

- Você não está seguro do que diz? Vai novamente mudar, deslocar-se em relação às questões que lhe são colocadas, dizer que as objeções não apontam realmente para o lugar em que você se pronuncia? Você se prepara para dizer, ainda uma vez, que nunca foi aquilo em que você se critica? Você já arranja a saída que lhe permitirá, em seu próximo livro, ressurgir em outro lugar e zombar como faz agora: não, não, eu não estou onde você me espreita, mas daqui de onde o observo rindo.

- Como?! Você pensa que eu teria tanta dificuldade e tanto prazer em escrever, que eu me teria obstinado nisso, cabeça baixa, se não preparasse - com as mãos um pouco febris - o labirinto onde me aventurar, deslocar meu propósito, abrirlhe subterrâneos, enterrá-lo longe dele mesmo, encontrar-lhe desvios que resumem e deformam seu percurso, onde me perder e aparecer, finalmente, diante dos olhos que eu não terei mais que encontrar? Vários, como eu sem dúvida, escrevem para não ter mais um rosto. Não me pergunte quem sou e não me diga para permanecer o mesmo: é uma moral de estado civil; ela rege nossos papéis. Que ela nos deixe livre quando se trata de escrever. (Foucault, 2010a, p. 19-20).

Toda uma poética da mutação textual é-nos aqui também prometida. A necessidade de cunhar conceitos e aplicar diferentes instrumentos de análise, com que sempre nos presenteia nos seus livros, passou em Foucault a estar menos ligada à recepção e assimilação, em bloco, de uma determinada herança intelectual do que à possibilidade de construir uma forma de produzir conhecimento que, por isso mesmo, se diria ser de tipo idiomático. O confronto com 
as sucessivas realidades em estudo, tomassem elas um cunho mais de tipo histórico, filosófico, literário, político ou outro qualquer, supunha a confecção de toda uma utensilagem específica e de uma nomenclatura inteiramente nova, mas que se devia exaurir por completo no interior das narrativas em que haviam sido geradas. Destarte, os seus trabalhos parecem querer dar-se a conhecer não tanto enquanto veículos de uma paisagem definida, mas, na inversa, como um modo singular de a construir e a ir fazendo acontecer aos olhos dos seus leitores que seguramente queria tomar de surpresa. Parece-nos que, enquanto investigadores, podemos reconhecer aqui uma interpelação ousada, queremos dizer, o endereçamento de um convite à livre invenção. Com efeito, os textos de Foucault materializam em si uma importante possibilidade, a de que o trabalho científico possa forjar na sua inteireza os objetos sobre os quais aparentemente estaria apenas autorizado a descrever ou a discorrer.

As declarações explicativas acerca da natureza do seu trabalho davam conta em Foucault de um desejo, que parece ficar mais transparente à medida que o lemos, em dar corpo a uma filosofia da diferença. Na verdade, iam-se sucedendo nele as entrevistas e os debates em que ficava bem patente a rejeição de todas as tentativas de o capturar e encapsular num saber disciplinar clássico, o que supunha que a natureza do seu labor apenas pudesse ser inteligível nos planos do hibridismo, do trânsito permanente das fronteiras, da experimentação e da ultrapassagem. Era por essa razão, acreditamos, que dizia que gostava de se imaginar também entre "pedras de espera" e "pontos de suspensão" ou que considerava os materiais que ia publicando "como proposições, e ofertas de jogo" abertas a todos quantos nele quisessem participar. Repetia que não tomava os seus livros "nem como tratados de filosofia nem estudos históricos"; surgiam-lhe, antes e no melhor dos casos, como "fragmentos filosóficos em canteiros históricos" (Foucault, 2006c, p. 336). Tome-se, como exemplo, o caso do seu último grande projeto de escrita, o da História da sexualidade, iniciado em 1976 com aparecimento do primeiro volume mas concluído somente oito anos depois com a publicação dos segundo e terceiro. As previsões iniciais de Foucault foram-se alterando significativamente no decurso da pesquisa e a introdução ao segundo volume, intitulado $O$ uso dos prazeres, dava conta do resultado a que chegara a sua exigência "de reformulação teórica e metodológica", após tantos e variados "riscos", "interrogações" e "abandonos". O estudo que então oferecia ao público leitor era, portanto, o resultado de uma pragmática que materializava um exercício "longo, hesitante e que frequentemente precisou de se retomar e corrigir”. O programa de publicação previsto de início desorganizara-se ao longo do processo de trabalho. Aos poucos o exercício foi-se tornando intimamente "filosófico", consistindo essa atitude em procurar "saber em que medida o trabalho de pensar sua própria história pode liberar o pensamento daquilo que ele pensa silenciosamente, e permitir-lhe pensar diferente". Foucault deteve-se aí em considerações acerca do seu impulso motivacional, isto é, de "uma curiosidade praticada com um pouco de obstinação": não a que procurasse reter o que lhe convinha saber, mas, antes, a que permitisse "separar-se de si mesmo". O ato de conhecer afastava-se, pois, da lógica tradicional do reconhecimento, da legitimação do que se sabe de antemão, da demonstração e da prova, para inaugurar, no seu lugar, uma dinâmica do olhar e do refletir em direção ao diverso, ao distante, à mudança de horizonte. Uma interrogação determinante tomava então vulto: "de que valeria a obstinação do saber se ele assegurasse 
apenas a aquisição dos conhecimentos e não, de certa maneira, e tanto quanto possível, o descaminho daquele que conhece?" (Foucault, 1994, p. 13-16). Noutro texto, mas ainda sobre o tipo de estímulo que tinha tido para se fixar no projeto da História da sexualidade, adiantaria:

O motivo que me impulsionou é muito simples. Para alguns, espero que ele possa bastar por si só. É a curiosidade; o único tipo de curiosidade que, de qualquer forma, vale a pena ser praticada com um pouco de obstinação: não aquela que busca se assimilar ao que convém conhecer, mas a que permite desprender-se de si mesmo. De que valeria a obstinação do saber se ela apenas garantisse a aquisição de conhecimentos, e não, de uma certa maneira e tanto quanto possível, o extravio daquele que conhece? Há momentos na vida em que a questão de saber se é possível pensar de forma diferente da que se pensa e perceber de forma diferente da que se vê é indispensável para continuar a ver ou a refletir. Talvez me digam que esses jogos consigo mesmo devem permanecer nas coxias, e que, na melhor das hipóteses, fazem parte desses trabalhos de preparação que desaparecem por si mesmos a partir do momento em que produzem efeitos. Mas o que é então a filosofia hoje - quero dizer, a atividade filosófica - senão o trabalho crítico do pensamento sobre si mesmo? E se ela não consistir, ao invés de legitimar o que já se sabe, em tentar saber como e até onde seria possível pensar de modo diferente? Há sempre algo de derrisório no discurso filosófico quando ele pretende, do exterior, estabelecer a lei para os outros, dizer-lhes onde está a sua verdade e de que maneira achá-la, ou quando pretende demonstrar-se por positividade ingênua; porém, é seu direito explorar o que, em nosso próprio pensamento, pode ser modificado, pelo exercício que ele faz de um saber que the é estranho. O "ensaio" - que é preciso entender como experiência transformadora de si mesmo e não como apropriação simplificadora de outrem - é o corpo vivo da filosofia, se pelo menos esta for ainda o que era antigamente, ou seja, uma “ascese", um exercício de si, no pensamento. (Foucault, 2004d, p. 196-197).

Concebida nestes termos, a prática da escrita colocava-se ao serviço de uma arte de existir, consistindo no sistemático trabalho de desprendimento de si mesmo. Tratava-se de empreender uma modalidade ética que explicitamente se situava nos antípodas da conversão do outro. É-se para si escrevendo livros, parecia estar sempre a repetir Foucault, sendo que em cada um deles a análise devia descobrir novas formas de interrogar os postulados, sacudir os hábitos, as maneiras de fazer e pensar, dissipar as familiaridades aceites. Uma e outra vez sustentou que os seus livros eram "fragmentos de autobiografia" (Foucault, 2002, p. 343) e que haviam sido as suas experiências nos hospitais psiquiátricos, com a polícia ou no terreno da sexualidade a determinar as temáticas das investigações em que se embrenhara profundamente. As suas palavras podiam então assumir um tom confessional que jamais tomariam em qualquer outro domínio, posto que sempre se recusou a falar da sua existência privada. "Na minha vida pessoal", relatou numa entrevista a Roger Pol-Droit gravada em junho de 1975, "eu me senti, desde o despertar da minha sexualidade, excluído, não verdadeiramente rejeitado, mas pertencendo à parte sombria da sociedade”. Para ele esse era, 
sem qualquer dúvida, "um problema impressionante quando descoberto por si mesmo" e que muito rapidamente, se transformaria "numa espécie de ameaça psiquiátrica: se você não é como todo mundo, é porque é anormal, se você é anormal, é porque é doente". A partir da sua vivência íntima terá compreendido que estas três categorias - "não ser como todo mundo, não ser normal e ser doente" - eram, entretanto, "muito diferentes" entre si, mas se achavam socialmente "assimiladas umas às outras" (Foucault, 2006b, p. 69-71).

O contexto de produção do seu primeiro livro, História da loucura, foi também longamente abordado numa conversa com M. Osório em novembro de 1977 e que veio a sair nos Quadernos para el dialogo. É sabido que naquela investigação havia tratado não tanto da loucura, mas da sua percepção enquanto doença mental e do estatuto que passou a ser dado aos loucos na Europa entre o século XVI e o começo do XX. Foucault informou que, após os seus estudos de filosofia, fora em 1955 trabalhar num hospital psiquiátrico em SainteAnne "com um estatuto particular", uma vez que "a profissão de psicólogo nos hospitais psiquiátricos não existia ou começava, apenas, a se desenhar, ao menos na França". Ficou dois anos numa espécie de estágio-limbo, sem uma tarefa específica, mas tolerado pelos profissionais de saúde, o que lhe terá permitido "circular na fronteira" entre dois mundos. E admitiu em seguida: "as relações entre médicos e doentes, as formas de instituição, ao menos nos hospitais psiquiátricos, espantaram-me, surpreenderam-me, e levaram-me até mesmo à angústia". E daí viria a deduzir o seu objecto de estudo, tendo-se pois colocado a questão não tanto de saber o que se desenrolava na cabeça dos doentes, mas de compreender uma dinâmica relacional tão "tensa e dramática". Terá intentado compreender o que se passava entre médicos e doentes "através dos muros, das regras, dos hábitos, dos constrangimentos, das coerções, das violências". Mesmo se o comum das práticas fosse organizado e justificado por um "discurso científico", o que sobressai e permanece "é não mais do que um relacionamento muito estranho... de luta, de afrontamento, de agressividade". Em uma palavra, "quis fazer a história, de alguma maneira, desse relacionamento entre a razão e a loucura", procurando dessa forma contribuir para uma discussão mais geral em torno dos procedimentos pelos quais a sociedade moderna se determinou em introduzir mecanismos de diferenciação entre os indivíduos. Então terá sido, "por razões pessoais, biográficas”, que se atirou "de corpo inteiro na poeira dos arquivos", tentando encontrar "documentos, textos, testemunhos concernentes ao estatuto da loucura" na modernidade. Deste registro referente ao trabalho do jovem Michel Foucault ficaria para sempre a evidência de que as suas "formas de reflexão" eram imediatamente "atadas, alimentadas, nutridas por experiências vividas" (Foucault, 2010d, p. 155-159).

Entretanto, nada disto era novidade nele. No prefácio que havia redigido para a edição inglesa de As palavras e as coisas, publicado ainda em 1970, reconheceu também que "numerosas coisas", enquanto as ia escrevendo, "não estavam claras" e que enquanto "algumas pareciam muito evidentes" outras, pelo contrário, surgiam-lhe "muito obscuras" (Foucault, 2008a, p. 182). Diria depois, sobre A arqueologia do saber, que havia aí buscado analisar um sistema de pensamento que lhe era "pessoal" e que o livro mais não espelhava do que a maneira como, por intermédio de conexões as mais diversas, o havia conseguido escrever (Foucault, 2006d, p. 316). Certamente que queria que o imaginássemos assim 
tomado de múltiplos instantes que o fizessem modificar pontos de vista, operar deslizamentos, roturas e fendas, como se na sua escrita pudesse reverberar a mobilidade geral que sentia atingir o mundo. Dir-se-ia que o tema da distância do pensamento, melhor dito, da viagem do pensamento, estava na origem da sua prática da escrita. Em abril de 1979 publicou em Le nouvel observateur uma pequena recensão crítica ${ }^{1}$, à que deu o expressivo título de Para uma moral do desconforto, e nela exprimiu uma das que ficariam conhecidas como máximas éticas: "minha maneira de não ser mais o mesmo é, por definição, a parte mais singular do que sou". A análise que fazia da sua trajetória era, portanto, a de alguém cuja "exigência de identidade" e "injunção de romper" confluíam para sentir a violência do mundo também na relação consigo mesmo (Foucault, 2010c, p. 280, grifo nosso).

De súbito as declarações de Michel Foucault acercavam-se de pesadelos e de formas singulares de prazer, envolvendo e ligando sempre o tempo antigo com o presente, numa obsessão expressa de articular e fusionar nele o ser mesmo da linguagem. A primeira vez que se debruçou sobre este tema familiar foi ao jornalista Claude Bonnefoy, do Le Monde, ainda em 1966. À pergunta sobre como teria inicialmente abordado a escrita, Foucault responderia com a lembrança de uma experiência assaz dura e que o colocou, também a ele e enquanto criança, no epicentro da violência maior da instituição escolar. A duras penas terá compreendido que a escrita corresponde ao princípio da legibilidade do conforme e que este não parece ter condições de se consolidar senão na anterioridade, no afastamento e, por que não afirmá-lo, na ausência da experimentação inventiva. "Uma das minhas lembranças mais constantes, certamente não a mais antiga, mas a mais obstinada", reconhecia de largada, "é a das dificuldades que tive para escrever bem". E precisava: "escrever bem no sentido em que se entende o termo na escola primária, ou seja, criar páginas de escrita bem legíveis". Terse-á tomado da evidência que ele era, em toda a sua classe e mesmo na sua escola, "o mais ilegível", situação essa que se terá mantido "por muito tempo, até aos primeiros anos do ensino secundário". Daí Foucault admitir que, também ele, tinha então uma relação "complicada" e "sobrecarregada" com esta prática. Àquela recordação primordial juntaria uma outra. A de que o "desejo de escrever" só surgiu nele relativamente tarde, quando tinha cerca de 30 anos e estava fora da França. A experiência de viver na Suécia a partir de meados da década de 1950 - e cuja língua admitia falar "mal", assim como o inglês, que praticava com muita dificuldade - impedia-o de dizer "o que realmente queria durante semanas, meses, anos" e tê-lo-á feito compreender que podia "habitar" a sua própria língua. Em vez de se querer esgotar numa fala que seria para ele sempre deficitária, constantemente "travestida" e "simplificada", fê-lo perceber que a língua materna possuía para ele uma "espessura", "consistência" na qual se poderia mover com grande à vontade. Como se lhe fossem acessíveis "suas leis próprias, seus corredores, suas linhas, seus declives, suas costas, suas irregularidades". A prática regular da escrita nascera, portanto, para Foucault, "nesse lugar sem lugar" que era o do país estrangeiro em que residia, mas para lhe fornecer um tipo de experiência do deslocamento e da desterritorialização que não mais o abandonou. Sentia que tinha diante de si uma "fisionomia" e uma "paisagem" na qual podia "caminhar e descobrir em volta das palavras e das frases, de repente, pontos de vista que não apareciam até então". 
A palavra "escrita" terá adquirido a partir dali "um certo valor", transformando-se para sempre num "modo de existência" (Foucault, 2004b, n. p.).

Foucault compreendia bem a vertigem paradoxal em que o ofício da escrita o envolvia. Reconhecia-se inteiramente instalado numa arte, que dizia em absoluto prazerosa e doce para si, de pôr a nu, um após outro, os episódios singulares e bizarros da grande fábula do mundo. Ir ao fundo do desejo, e nele se manter por toda uma vida, tecendo as modalidades históricas do arbitrário, do sem fundamento e da morte de todas as verdades do homem. E ousar permanecer nessa céptica inventividade, mesmo sabendo que ela jamais anularia o vazio de conhecimento - lembrado em pesadelo recorrente - que a linguagem sempre instaura no espírito de quem se sente unicamente interpelado por ela.

\subsection{A análise do discurso}

Desde o momento em que se dera a sua "conversão total" à escrita, Foucault viu-se confrontado, ato contínuo, com a materialidade das palavras. O problema que o acompanhava era, efetivamente, o de tentar compreender, numa cultura e sociedade como as nossas, "que significa a existência das palavras, da escrita, do discurso?". Reconhecia que a sua investigação decorria de uma constatação corrente e banal, que também o inquietava desde muito cedo - a de que nunca "atribuímos importância tão grande ao fato de que, afinal, o discurso existe". Permaneceu mobilizado para mostrar que este seria certamente mais do que uma "película transparente" ou um "espelho" através do qual enxergamos ou pensamos nas coisas. Persuadia-se que, tal como sucedia no mundo da economia, também seria possível determinar a consistência e a densidade das "leis do discurso". Porém, as suas perguntas de investigador não iam no sentido de analisar a estrutura da linguagem, tal como então a faziam os linguistas, que discutem o discurso enquanto sistema de signos, mas sim o que denominava de "discurso real". Tratava-se de operar "uma análise das coisas ditas, na medida em que são coisas", explicava ainda Le Monde (Foucault, 2004b, n. p.). Tudo em Foucault parecia concorrer para exprimir nele e ou a partir dele, ia dar no mesmo, a evidência de que o discurso é ação, que fabrica seres e objetos sobre que aparentemente apenas discorre ou descreve. $\mathrm{Na}$ origem do seu trabalho de investigação está, assim, a premissa de que a linguagem constitui o mundo, não se limitando a uma mera função ideológica, de homologia ou de reflexo dele.

Eis o ponto: escrever e problematizar todas as dimensões, todas as possibilidades estratégicas de produção do discurso. Inúmeras vezes Foucault escreveu que procurava tomar o discurso nas "condições de formação, na série de suas modificações e no jogo de suas dependências e de suas correlações", fazendo-o aparecer numa relação susceptível de ser descrita "com o conjunto de outras práticas". Terá pensado conceitualmente num sistema regrado, constituído por diferenças, dispersões, defasagens, interstícios e distâncias entre enunciados, que também proliferariam indefinidamente e sempre em relação com acontecimentos de ordem diversa. Por isso, sugeria a possibilidade de uma transversalidade disciplinar no domínio da análise do passado, à qual de resto nunca se deixou de dedicar. Ao invés de partirmos de "uma história econômica, social, política, englobando uma história do 
pensamento", e também "em vez de lidarmos com uma história das ideias", que se referisse a condições extrínsecas, entendia que se poderia intentar uma "história das práticas discursivas" nas relações específicas que as articulariam com as "outras práticas". Nestes termos não estava em causa para ele "compor uma história global" - que reagrupasse todos os seus elementos em torno de um princípio ou de uma forma única -, mas de encontrar forma de "desdobrar o campo de uma história geral" (Foucault, 2010e, p. 15).

A opção levou, não raro, Foucault a ter de esclarecer que partia do discurso tal qual se apresentava e do consequente postulado de que nada havia escondido por detrás dele. Tratava-se de afirmar a "neutralidade primeira" e conduzir a análise para a "descrição pura dos fatos de discurso" (Foucault, 2008b, p. 92). Procurava, deste modo, demarcar-se objetivamente de dois "recursos tradicionais" de que se alimentavam à época as ciências sociais e humanas. O primeiro, que denominava de "histórico-transcendental", correspondia àquela tentativa que procurava, "para além de toda manifestação e de todo nascimento histórico, uma fundação originária, a abertura de um horizonte inesgotável", um projeto analítico que estaria em "retrocesso" relativamente a todo acontecimento, e que manteria através da análise histórica o propósito de estabelecer uma "unidade". O segundo era por ele identificado como "recurso empírico ou psicológico" e consistia na tentativa de "procurar cuidadosamente o fundador", interpretar as suas afirmações, "detectar as significações implícitas" que jaziam "silenciosamente em seu discurso", para em seguida "seguir o fio ou o destino dessas significações, narrar as tradições e as influências, fixar o momento dos despertares, dos esquecimentos, das tomadas de consciência, das crises, das mudanças no espírito, na sensibilidade ou no interesse dos homens". Entendia que o primeiro desses recursos era "tautológico" e o segundo "extrínseco e não essencial” (Foucault, 2010e, p. 3).

Este diagnóstico como que lhe impunha a necessidade de formular um modelo de trabalho alternativo ao prevalecente entre os seus colegas historiadores. Foucault empreendeu, pois, a sistematização de uma metodologia dominada pelo princípio da plasticidade, a qual o autorizaria a identificar "grandes unidades" e compreendê-las tanto na simultaneidade quanto na sobreposição ou na sucessão. Digamos, para simplificar, que a sua análise terá necessitado de "três grupos de critérios" para se aproximar da coisa dita e se demarcar das análises hegemônicas da sua própria época. O primeiro grupo seria constituído pelos "critérios de formação". Aí começava por esclarecer que, em sua opinião, a individualização de um discurso, "como a economia política ou a gramática geral", não podia continuar a ser construída sobre os princípios teóricos da "unidade de um objeto" e da sua "estrutura formal", de "uma arquitetura conceitual coerente" ou, por último, de "uma escolha filosófica fundamental". Bem ao contrário, uma formação discursiva seria individualizada cada vez que existissem "regras de formação" para todos os seus objetos, para "todas as suas operações", para "todos os seus conceitos", para "todas as suas opções teóricas; e tudo isto por mais dispersos, sobrepostos, encadeados, incompatíveis e excludentes que uns e outras se apresentassem entre si. Em seguida vinham os "critérios de transformação ou de limiar". Entendia que, por exemplo, a história natural ou a psicopatologia podiam ser tomadas enquanto "unidades de discurso", sempre que ele como investigador fosse capaz de: (i) detectar quais as condições que concorreram para, num momento muito preciso do tempo 
histórico, terem sido formados "objetos, operações, conceitos e opções teóricas"; (ii) definir quais "as modificações internas" por que passariam; (iii) definir, enfim, "a partir de que limiar de transformação" outras regras puderam ter sido postas em jogo. Em terceiro lugar vinham "os critérios de correlação". Foucault diria ainda, a título de ilustração, que o caso da medicina clínica podia ser tomado como o de "uma formação discursiva autônoma", se pudesse ser estabelecido "o conjunto das relações" que a definiam e a situavam "entre os outros tipos de discurso (como a biologia, a química, a teoria política ou a análise da sociedade) e no contexto não discursivo no qual funciona (instituições, relações sociais, conjuntura econômica e política)" (Foucault, 2010e, p. 3-4).

Consequentemente, havia que esboçar uma aparelhagem teórica que permitisse tratar toda uma variedade de acontecimentos no espaço do discurso. Como se, por seu intermédio, Foucault acreditasse que lhe seria possível chegar ao "inconsciente não do sujeito falante, mas da coisa dita" (Foucault, 2008b, p. 105-106). Em sua opinião, o que se descobre sempre na língua falada não é "um tesouro muito rico de palavras", mas, antes, "uma multiplicidade de enunciados". Diversamente à constante morfológica e referencial com que a palavra surge no dicionário, haveria agora que procurar "uma significação diferente" e estabelecer uma série imprevista. Em Foucault, a palavra só existe "por aderir a uma cena em que surge como grito, murmúrio, comando, narrativa"; ela "é o paradoxo, o milagre, o maravilhoso acaso de um mesmo ruído que, por razões diferentes, personagens diferentes, visando a coisas diferentes, ressoam ao longo de uma história" (Foucault, 2009b, p. 305). Era assim que as unidades tradicionais se poderiam ver substituídas por regras que cobrissem todos os aspectos da formação do discurso e remetessem para a organização dos objectos, nos seus vários tipos "sintácticos", "semânticos" e "operacionais". Ora, sempre que num "grupo de enunciados" fosse possível "observar e descrever um referencial, um tipo de defasagem enunciativa, uma rede teórica, um campo de possibilidades estratégicas", podia então estar-se seguro de que eles pertenciam ao que Foucault viria a chamar de "formação discursiva". Essa formação agruparia, portanto, "toda uma população de acontecimentos enunciativos" mas em permanente articulação (Foucault, 2008b, p. 105-106).

"Chamaremos de discurso", precisava ele de novo em A arqueologia do saber, "um conjunto de enunciados, na medida em que se apóiem na mesma formação discursiva"; o discurso "não forma uma unidade retórica ou formal, indefinidamente repetível" e cujo aparecimento podemos assinalar na história, mas é constituído por "um número limitado de enunciados" para os quais podemos definir um conjunto de condições históricas de existência. Da mesma maneira, uma outra conhecida expressão sua, a de "prática discursiva", adquirirá agora um sentido mais claro. Não devendo ser confundida com uma actividade racional ou até com "a operação expressiva pela qual um indivíduo formula uma ideia, um desejo, uma imagem", Foucault definia a prática discursiva como "um conjunto de regras anónimas, históricas, sempre determinadas no tempo e no espaço, que definiram, em uma dada época e para uma determinada área social, económica, geográfica ou linguística, as condições de exercício da função enunciativa" (Foucault, 2010a, p. 132-133).

O modelo conceptual que Foucault apresentou para a análise do discurso não tem, a nosso ver, outra utilidade a não ser a de nos levar a compreender que nenhum enunciado pode 
receber da lei, sob alguma das suas formas, sejam mais provisórias ou eternas, nenhuma verdade que o cerque. Eis-nos perante um repto para que a imaginação do investigador possa enfim descobrir-se numa relação face a face com a própria linguagem. Sem que nenhum tipo de limite ou intimação se interponha. É esse o domínio para que nos procuramos ainda dirigir.

\subsection{Autorreflexividade acadêmica}

A fim de tornar claro o posicionamento de Michel Foucault, torna-se necessária a explicitação de uma tomada de posição complementar. Com frequência repetia que, para ele, pensar outra coisa não era senão a elaboração de um trabalho crítico que incidia sobre o seu próprio pensamento. Ora, essa asserção trazia no bojo o desígnio de questionar de frente o território social em que o seu próprio discurso se desencadeava. O jogo de produção da diferença como que impunha uma permanente vigilância ante o locus de dimanação, circulação e validação da própria linguagem científica. Havia, pois, que refletir criticamente sobre a multiplicidade de regras e mecanismos institucionais que se abatiam sobre ela. Cumpre verificar que a consciência acerca deste outro procedimento foi também bem matinal em Foucault. Tome-se esta declaração proferida ainda no verão de 1968 num debate no Círculo de Epistemologia e inserta nos Cahiers pour l'analyse:

Analiso o espaço em que falo. Exponho-me a desfazer e a recompor esse lugar que me indica as balizas primeiras do meu discurso; tento dissociar dele as coordenadas visíveis e sacudir sua imobilidade de superfície: arrisco suscitar a cada instante, sob cada uma de minhas proposições, a questão de saber de onde ele pode nascer: pois tudo isso que digo poderia ter como efeito deslocar o lugar de onde eu o digo. Embora aí esteja a questão: de onde você pretende falar, você que quer descrever - de tão alto e de tão longe - os discursos dos outros? Responderei somente: eu acreditei que falava do mesmo lugar que esses discursos e que, definindo seu espaço, eu situaria minha intenção; mas devo agora reconhecê-lo: de onde mostrei que eles falavam sem dizê-lo, eu mesmo só posso falar a partir dessa diferença, dessa ínfima descontinuidade deixada, já detrás dele, por meu discurso. (Foucault, 2008b, p. 96-97)

As renovadas possibilidades de idas e vindas proporcionadas pela escrita terão levado Foucault a admitir que sonhava "com uma nova era da curiosidade", toda uma filosofia de vida, um tom novo, uma nova maneira de olhar e de pensar o trabalho científico que fizesse calar o desejo de "monarquia" ou de tutela que tão frequentemente se abatia sobre ele. Tratava-se de valorizar uma postura que o "cristianismo, a filosofia e até uma certa concepção da ciência" haviam durante séculos estigmatizado como mais um vício e tornado sinônimo de "futilidade". Para Foucault a palavra curiosidade deveria, ao contrário, ser traduzida por "inquietação", remetendo para a responsabilidade que se assume pelo que existe e se pensa possa existir. Haveria, em sua opinião, que criar redes e encontrar formas de desmultiplicar a informação, para que então pudessem surgir e atuar "diferenciações úteis" no plano da 
construção e da circulação do saber. Entrevia a possibilidade de toda uma postura ética no interior das instituições de saber que tivesse uma consciência aguda do real - em lugar de se imobilizar nele -, que ora estranhasse ora achasse singular tudo quanto se movia ao seu redor. "Uma certa obstinação em nos desfazermos de nossas familiaridades e de olhar de maneira diferente as mesmas coisas; uma paixão de apreender o que se passa; uma desenvoltura, em relação às hierarquias tradicionais, entre o importante e o essencial" - precisava. Curiosidade, enfim, como o motor que fizesse fazer agir as diferenças - opondo-se abertamente a uma ideia corrente da universidade como "zona reservada" e "parque cultural" dos "sábios ameaçados" pela vulgarização cultural -, dando lugar a um novo entendimento da filosofia. E esta disciplina podia mesmo passar a ser vista como o movimento ou a actividade crítica por meio da qual, "não sem esforços, hesitações, sonhos e ilusões, nos separamos daquilo que é adquirido como verdadeiro, e buscamos outras regras de jogo". Nestes termos havia que modificar por completo a missão da formação recebida nas instituições de ensino superior. Era necessário que estas pudessem ser pensadas de tal modo que permitisse "ao indivíduo modificar-se a seu gosto", o que somente aconteceria se o ensino passasse a ser "uma possibilidade aberta permanentemente". A sua hipótese remetia aqui, como já por certo se adivinha, para a democratização não apenas do acesso à informação científica, mas de todos os meios e processos que permitem a produção e recriação infinita do saber: "digo que a distribuição das pessoas em uma cultura deve ser incessante e tão polimorfa quanto possível". A hierarquia universitária também era abertamente questionada por Foucault: "não deveria existir, por um lado, essa formação à qual nos submetemos e, por outro, essa informação à qual se é submisso". Para tanto, havia que fazer ressaltar uma interferência que no limite os seus textos procuravam ilustrar - da investigação, fosse ela de cariz teórico ou empírico, com as "mudanças no comportamento, na conduta real das pessoas, em sua maneira de ser, em sua relação consigo mesmas e com os outros" (Foucault, 2006d p. 305306). Estas palavras têm para nós o maior significado enquanto investigadores que trabalham a partir do campo da educação.

Se o que por via de uso entendemos por criatividade parecia sustentar em Foucault toda uma arte de viver, então a defesa não cessava de lhe impor a necessidade de mais considerações e esclarecimentos acerca da relação dinâmica entre ser e saber. Empregava a palavra "saber" para estabelecer uma distinção com "conhecimento". Visava, com "saber, um processo pelo qual o sujeito sofre uma transformação por aquilo mesmo que ele conhece, ou, antes, por ocasião do trabalho que efetua para conhecer. Uma operação que permitia, a um tempo, "modificar o sujeito e conhecer o objeto". A compreensão de que os procedimentos de inteligibilidade e racionalidade tinham esta vocação faria certamente com que a análise, em lugar de se retrair, deslocasse sem parar os seus focos (Foucault, 2010b, p. 338-339).

Michel Foucault defendia para si uma identidade dupla, a de universitário e de intelectual, quer dizer, a de alguém cuja razão de ser era a de tentar "fazer funcionar um tipo de saber e análise que era ensinado e aceite na universidade, de modo a modificar não somente o pensamento dos outros, mas também o seu próprio" (Foucault, 2004d, p. 248). Insistiu no postulado segundo o qual o "eu não nos é dado" e que, dessa evidência 
fundamental, se poderia tirar também a "consequência prática" mais decisiva, a de nos "criarmos a nós mesmos como obra de arte". A ética da existência foucaultiana - sempre apresentada como "a prática refletida da liberdade" (Foucault, 2004a, p. 267) - descobria assim autocriação onde outros encontravam quase sempre autenticidade. Nessa perspectiva, defendia que não se deveria referir a atividade criativa de alguém ao tipo de relação que tinha consigo mesmo, mas, na inversa, a "relacionar a forma de relação que se tem consigo mesmo à atividade criativa". Era então que se mostrava surpreendido que, no mundo social contemporâneo, a arte se tivesse transformado "em algo relacionado a objetos e não a indivíduos ou à vida", lastimando que remetesse apenas a uma prática especializada feita por artistas. E por isso lançava duas perguntas-repto: "entretanto, não poderia a vida de todos se transformar numa obra de arte? por que deveria uma lâmpada ou uma casa ser um objeto de arte, e não a nossa vida?" (Foucault, 1995, p. 261-262). Parecia acreditar que uma multidão de estilos de existência irromperia a partir de uma prática de trabalho diário como o seu nas instituições de ensino superior. Em lugar de remeter para a concordância e harmonia de idéias, a "chave da atitude pessoal" de um filósofo deveria, para Michel Foucault, ser deduzida da sua "filosofia como vida, na sua vida filosófica, no seu ethos (Foucault, 2004c, p. 219). Eis porque dizia que não fazia nenhum tipo de esforço "para desenvolver a menor forma de coerência" e que esta mais não era que a sua vida.

Foucault, assumia que a coerência era essencialmente de "natureza estratégica" e apenas conduzida pelo modelo de espiritualidade que tomava para si mesmo: "se eu luto por tal questão ou por tal outra, eu o faço porque, de fato, essa luta é importante para mim, em minha subjetividade", concluía (Foucault, 2002, p. 343-344). Tome-se esta outra confissão: "eu acredito, seguindo Nietzsche, que a verdade deva ser compreendida em termos de guerra; a verdade da verdade é a guerra" (Foucault, 2006b, p. 99). Parece-nos estar a dizer que, a seu ver, eram, pois, unicamente os mecanismos de poder que asseguravam a coação do verdadeiro. A prática da escrita, tal como a vinha concebendo, corresponderia a uma convocação para o combate mais violento de todos. Aquele que impunha um permanente espírito de vigília e se dirigia por inteiro à lei moral para encontrar meios e forma de a estiolar. Como se ele nos estivesse sempre a querer mostrar que o traçado que a verdade expressa será sempre do domínio do fortuito e nunca o de caminho que possamos tomar como certo. Eis, pois, como um projeto pessoal de investigação foi também inteiramente construído para ser recebido enquanto incitamento ao pensar desassombrado, a uma escrita polimorfa. Por isso é que os seus livros, mesmo tendo uma superfície única de emergência, não indicam uma ordem submetida à unidade; tão somente a busca crítica da palavra e da análise plural.

Fiz meus estudos entre 1948 e 1952-1955; era uma época em que a fenomenologia estava ainda dominante na cultura europeia. $O$ tema da fenomenologia era reinterrogar as evidências fundamentais. Tomando distância, se possível, a fenomenologia, reconheço de bom grado - e se reconhece isso, certamente, a partir do momento em que se tem mais idade - que, finalmente, não se saiu da questão fundamental que nos foi colocada por tudo aquilo que fez a nossa juventude. Não saí, mas não parei de recolocar esta questão: "Será que o que é 
evidente deve, efetivamente, ser evidente? Será que não é preciso levantar as evidências, mesmo as mais pesadas?" É isso bater-se contra suas familiaridades, não para mostrar que se é um estranho em seu próprio país, mas para mostrar o quanto o seu próprio país lhe é estranho e como tudo o que o cerca e tem o ar de fazer uma paisagem aceitável é, de fato, o resultado de uma série de lutas, de conflitos, de dominações, de postulados etc. (Foucault, 2010e, p. 374).

É verdade que tratei, prioritariamente, fenómenos do passado: o sistema de exclusão e a prisão dos loucos na civilização europeia do século XVI ao século XIX, a constituição da ciência e da prática médicas no início do século XIX, a organização das ciências humanas nos séculos XVIII e XIX. Mas, se me interessei - de fato, me interessei profundamente - por esses fenómenos foi porque vi neles maneiras de pensar e de se comportar, que são ainda as nossas. Tento pôr em evidência, fundamentando-me em sua constituição e sua formação histórica, sistemas que ainda são os nossos nos dias de hoje, e no interior dos quais nos encontramos apanhados. Trata-se, no fundo, de apresentar uma crítica de nosso tempo, fundamentada em análises retrospectivas. (Foucault, 2006d, p. 13).

Se Foucault teve um cuidado extremo em rodear de esclarecimentos o seu modus faciendi, é natural que nele se sucedessem igualmente as explicações relativas ao destino e uso que gostaria fosse feito dos seus textos. Neste passo da nossa narrativa o essencial do seu argumento já se antecipa sem dificuldade. Remete para o desejo de irradiação social e desmultiplicação da prática da escrita, numa recusa frontal à lógica tão enraizada de sacralização do autor e de associação do livro científico com a estabilização ordenada da verdade, consubstanciais à edificação do Estado moderno. Para quem não se cansou de afirmar que sempre se atinha ao que se passava nele e passava por ele, era quase automática a necessidade de sublinhar que as suas narrativas, embora de vocação crítica e envolvidas com situações as mais das vezes identificáveis na atualidade, apenas transportavam formas de questionamento e jamais propunham fazer lei, dar lições ou avisos em relação a determinada prática ou forma de organização da vida humana. Repetiu uma e outra vez que havia que ter coragem, ousadia intelectual e a maior fé na escrita que produzia, mas ser radicalmente modesto acerca do impacto, da influência e uso que ela pudesse ter sobre terceiros. Eis no essencial a posição de que partia: "penso que ninguém é insubstituível no interior de um trabalho teórico"; "o que eu disse qualquer um poderia dizer em meu lugar"; "nesse sentido, sou perfeitamente inútil" (Foucault, 2011, p. 158).

Terminamos. Em Foucault nada existe além da relação do sujeito e de todas as obras com a "experiência nua da linguagem". Eis por que o objeto de um discurso crítico, como o do seu próprio empreendimento, supunha o abandono de uma antropologia que insistisse na relação do homem quer com o mundo exterior, quer com os fantasmas da sua interioridade psíquica. A articulação a estabelecer não era tampouco a do literato com a língua, mas, ao invés, a do "sujeito falante com este ser singular, difícil, complexo, profundamente ambíguo (pois ele designa e concede seu ser a todos os outros seres, inclusive a ele mesmo) e que se chama linguagem" (Foucault, 2009a, p. 193). Daqui derivaria uma prática que ainda nos 
interpela e traz cativos: a que toma o discurso como objeto, supõe a multiplicidade interminável de relações entre enunciados e estabelece o de fora do olhar analítico, que assim produz uma escrita alimentada apenas de si mesma, sem sujeito, princípio ou fim. A ausência do autor garantia a continuidade infinita da produção textual.

Será possível uma paixão não triste desenvolver-se no interior de uma análise que se organiza a partir de visões tormentosas e de violências sem nome conduzidas exatamente em nome da vida? Qual positividade, a escrita de Michel Foucault aí está para responder que sim, que podemos imaginar sempre novas formas de existência e conduta, bem para lá da racionalização disponibilizada hic et nunc como prioridade ontológica ou enquadramento institucional. A rasura do estereótipo a que conduz a compreensão do arbitrário de qualquer grelha de conduta permite, outrossim, direcionar suavemente o nosso pensamento para a ideação de modos ambivalentes e heterodoxos, tanto de estar no mundo como de nos entendermos entre nós. Foucault escolheu - terá sido escolhido? - o tipo do seu artesanato intelectual sob impacto de uma cena-limite tornada possível pela tecnologia científica e pela dramaturgia da biopolítica do eu nos meados de novecentos. E hoje mesmo, em 2021, enfrentamos outra com a pandemia.

\section{Uma conversa infinita}

Blanchot (2001) no primeiro livro da série A conversa infinita, série em que mais uma vez o escrever constitui o tema de sua pesquisa, brinda-nos com a sabedoria: "a questão é o desejo do pensamento. [...] A resposta é a desgraça da questão" (Blanchot, 2001, p. 43). Acompanhados por Blanchot, não buscamos a resposta em nossa conversa, mas sim as condições de colocar a pergunta de uma forma um pouco mais larga, almejando abrigar novas formas de dizer e, com isso, apostando na constituição de um porvir que guarde abertura para novos modos de existir. No entender do autor, o trabalho escritural é desde sempre atingido por um efeito de desmultiplicação ou pela aproximação a outros espaços, porque é a própria verdade ou lei que por ele se vê posta em causa. No escritor - no pesquisador - encontra-se a mediação e o murmúrio que vão permitindo à linguagem, num processo de disseminação infinita, ir-se convertendo em imagem e argumento. Nesse processo ouve-se o eco do que não pode deixar de ser dito. As mudanças que se detectam no curso da linguagem não supõem que o escritor trabalhe numa região que se move por princípios racionais, que levem a glorificar-se a consciência, o progresso e a superação, num movimento ascensional em direção à verdade última e ao universal. $\mathrm{O}$ trabalho da questão impede o pensamento de tender para a unidade e de realizar o todo. A capacidade de nos mantermos em exercício neste jogo relacional com o curso do mundo e conosco mesmos está dependente de perceber que a maneira de ser da escrita se define pelo questionamento e que este, uma vez desencadeado, não termina nunca. A palavra torna-se o lugar da dispersão e da fuga do sentido porque existe uma fantástica força que produz um revezamento permanente entre o todo e o próprio ser.

Nossa convocação nesta escrita foi para que, acompanhados por Freud, Lacan e Foucault, pudéssemos tecer a sustentação de um espaço de escrita da pesquisa acadêmica que 
não se veja aprisionado em prescrições e formas hegemônicas. Pensamos que abrir espaço para um trabalho de escrita que é ele mesmo a própria pesquisa em andamento e não somente o registro de um caminho que lhe seria independente e anterior é parte de um exercício ético que dá lugar à invenção de um presente que inclui formas de existir até então não antecipadas. Pensar a linguagem como produtora de mundos, ainda que não controláveis por quem os nomeia, é contar com uma certa dose de abertura e indeterminação na produção de um conhecimento que se apresenta sempre carregado de uma certa dose de precariedade. É justo na precariedade do sentido que se assentam as condições de produção de um novo, como tão bem situou Hölderlin em seu conhecido verso: "Mas onde mora o perigo cresce também o que salva".

\section{Notas}

1. A um livro de Jean Daniel (1979) intitulado L'ère dês ruptures. Paris: Grace.

\section{Referências}

ADORNO, Theodor W. O ensaio como forma. In: Notas de Literatura I. São Paulo: Editora 34, 2011.

AGAMBEN, Giorgio. O fogo e o relato: ensaios sobre criação, escrita, arte e livros. São Paulo: Boitempo, 2018.

BARTHES, Roland. Da leitura. In: O rumor da língua. São Paulo: Martins Fontes, 2004.

BENSE, Max. O ensaio e sua prosa. Revista Serrote, n. 16, 2014. Disponível em: <https://www.revistaserrote.com.br/2014/04/o-ensaio-e-sua-prosa/>. Acesso em: 12 fev. 2021.

BLACHOT, Maurice. A conversa infinita: a palavra plural. São Paulo: Escuta, 2001.

BORGES, Jorge Luis. O Aleph. In 1999.

CERTEAU, Michel de. História e psicanálise: entre ciência e ficção. Belo Horizonte: Autêntica, 2011.

FOUCAULT, Michel. Arqueologia do saber. Rio de Janeiro: Forense Universitária, 2010a. (Trabalho original publicado em 1969)

FOUCAULT, Michel. Conversa com Michel Foucault. In: MOTTA, M. B. (Org.). Ditos \& escritos, v. 6: Repensar a política. Rio de Janeiro: Forense Universitária, 2010b. p. 289-347. (Trabalho original publicado em 1980)

FOUCAULT, Michel. Conversação com Michel Foucault. In: MOTTA, M. B. (Org.). Ditos \& escritos, v. 4: Estratégia, poder-saber. Rio de Janeiro: Forense Universitária, 2006a. p. 13-25. (Trabalho original publicado em 1971)

FOUCAULT, Michel. Entrevista com Michel Foucault. In: MOTTA, M. B. (Org.). Ditos \& escritos, v. 1: Problematização do sujeito: psicologia, psiquiatria e psicanálise. Rio de Janeiro: Forense Universitária, 2002. p. 331-344. (Trabalho original publicado em 1984)

FOUCAULT, Michel. Entrevista com Michel Foucault. In: MOTTA, M. B. (Org.). Ditos \& escritos, v. 7: Arte, epistemologia, filosofia e história da medicina. Rio de Janeiro: Forense Universitária, 2011. p. 157-168. (Trabalho original publicado em 1968)

FOUCAULT, Michel. A ética do cuidado de si como prática da liberdade. In: MOTTA, M. B. (Org.). Ditos \& 
escritos, v. 5: Ética, sexualidade, política. Rio de Janeiro: Forense Universitária, 2004a. p. 264-287. (Trabalho original publicado em 1984)

FOUCAULT, Michel. Eu sou um pirotécnico. In: POL-DROIT, R. Michel Foucault, entrevistas. São Paulo: Graal, 2006b. p. 67-100. (Trabalho original publicado em 1975)

FOUCAULT, Michel. História da sexualidade, v. 2: O uso dos prazeres. Lisboa: Relógio d'Água, 1994. (Trabalho original publicado em 1984)

FOUCAULT, Michel. O Mallarmé de J.-P. Richard. In: MOTTA, M. B. (Org.). Ditos \& escritos, v. 3: Estética: literatura e pintura, música e cinema. Rio de Janeiro: Forense Universitária, 2009a. p. 183-193. (Trabalho original publicado em 1964)

FOUCAULT, Michel. Mesa-redonda em 20 de maio de 1978. In: MOTTA, M. B. (Org.). Ditos \& escritos, v. 4: Estratégia, poder-saber. Rio de Janeiro: Forense Universitária, 2006c. p. 335-351. (Trabalho original publicado em 1980)

FOUCAULT, Michel. M. Foucault. Conversação sem complexos com um filósofo que analisa as "estruturas do poder”. In: MOTTA, M. B. (Org.). Ditos \& escritos, v. 4: Estratégia, poder-saber. Rio de Janeiro: Forense Universitária, 2006d. p. 306-316. (Trabalho original publicado em 1978)

FOUCAUlT, Michel. A palavra nua. Folha de São Paulo, São Paulo, 21 nov. 2004b. Disponível em: <http://www1.folha.uol.com.br/fsp/mais/fs2111200424.htm>. Acesso em: 21 fev. 2021.

FOUCAULT, Michel. Para uma moral do desconforto. In: MOTTA, M. B. (Org.). Ditos \& escritos, v. 6: Repensar a política. Rio de Janeiro: Forense Universitária, 2010c. p. 279-284. (Trabalho original publicado em 1979)

FOUCAULT, Michel. O poder, uma besta magnífica. In: MOTTA, M. B. (Org.). Ditos \& escritos, v. 6: Repensar a política. Rio de Janeiro: Forense Universitária, 2010d. p. 155-169. (Trabalho original publicado em 1977)

FOUCAULT, Michel. Política e ética: uma entrevista. In: MOTTA, M. B. (Org.). Ditos \& escritos, v. 5: Ética, sexualidade, política. Rio de Janeiro: Forense Universitária, 2004c. p. 218-224. (Trabalho original publicado em 1984)

FOUCAULT, Michel. Prefácio à edição inglesa. In: MOTTA, M. B. (Org.). Ditos \& escritos, v. 2: Arqueologia das ciências e história dos sistemas de pensamento. Rio de Janeiro: Forense Universitária, 2008a. p. 182188. (Trabalho original publicado em 1970)

FOUCAULT, Michel. Resposta a uma questão. In: MOTTA, M. B. (Org.). Ditos \& escritos, v. 6: Repensar a política. Rio de Janeiro: Forense Universitária, 2010e. p. 1-24. (Trabalho original publicado em 1968)

FOUCAULT, Michel. Sete proposições sobre o sétimo anjo. In: MOTTA, M. B. (Org.). Ditos \& escritos, v. 3 : Estética: literatura e pintura, música e cinema. Rio de Janeiro: Forense Universitária, 2009b. p. 299-312. (Trabalho original publicado em 1968)

FOUCAULT, Michel. Sobre a arqueologia das ciências. Resposta ao Círculo de Epistemologia. In: MOTTA, M. B. (Org.). Ditos \& escritos, v. 2: Arqueologia das ciências e história dos sistemas de pensamento. Rio de Janeiro: Forense Universitária, 2008b. p. 82-118. (Trabalho original publicado em 1968)

FOUCAULT, Michel. Sobre a genealogia da ética: uma revisão do trabalho. In: H. DREYFUS, H.; RABINOW, P. (Org.). Michel Foucault, uma trajetória filosófica. Rio de Janeiro: Forense Universitária, 1995. p. 253278. (Trabalho original publicado em 1983)

FOUCAULT, Michel. O uso dos prazeres e as técnicas de si. In: MOTTA, M. B. (Org.). Ditos \& escritos, v. 5: Ética, sexualidade, política. Rio de Janeiro: Forense Universitária, 2004d. p. 192-217. (Trabalho original publicado em 1983)

FREUD, Sigmund. Cartas de Sigmund Freud a Arthur Schnitzler. Formação freudiana, Rio de Janeiro. Disponível em: <https://www.freudiana.com.br/destaques-home/cartas-de-sigmund-freud-a-arthurschnitzler.html>. Acesso em: 12 de fev. 2021. (Trabalho original publicado em 1922) 
FREUD, Sigmund. O infamiliar. In: Obras incompletas de Sigmund Freud. Belo Horizonte: Autêntica. p. 27-125.

FREUD, Sigmund. Srta. Elisabeth Von R. In: Edição standard das obras psicológicas completas de Sigmund Freud, v. 2. Rio de Janeiro: Imago, 1996. p. 152-189 (Trabalho original publicado em 1895)

LACAN, Jacques. Escritos. Rio de Janeiro: Zahar, 1998.

LACAN, Jacques. Meu ensino. Rio de Janeiro: Zahar, 2006.

LACAN, Jacques. O seminário, livro 1 - A ética da psicanálise. Rio de Janeiro: Zahar, 1997. (Trabalho original proferido em 1959-1960)

LACAN, Jacques. O seminário, livro 5 - As formações do inconsciente. Rio de Janeiro: Zahar, 1999. (Trabalho original proferido em 1957-1958)

MATURANA, Humberto. Cognição, ciência e vida cotidiana. Belo Horizonte: Editora UFMG, 2001.

PORGE, Érik. Transmitir a clínica psicanalítica: Freud, Lacan, hoje. Campinas: Editora Unicamp. 2009.

RIVERA, Tania. Desejo de ensaio. In: RIVERA, Tania; CELES, Luiz Augusto; SOUSA, Edson Luiz André (Org.). Ensaios brasileiros contemporâneos: psicanálise. Rio de Janeiro: Funarte, 2017. p. 11-26.

STAROBINSKI, Jean. É possível definir o ensaio?. Remate de Males. Campinas, n. 31, p. 13-24, jan./dez. 2011.

\section{Correspondência}

Simone Zanon Moschen: Psicanalista, membro da Associação Psicanalítica de Porto Alegre, professora titular do Instituto de Psicologia - UFRGS - e dos Programas de Pós-graduação em Educação e em Psicanálise: Clínica e Cultura, ambos da UFRGS. Coordenadora do NUPPEC/UFRGS - Eixo Psicanálise, Educação e Cultura. Membro da Rede de Pesquisa Graphias. Bolsista Produtividade CNPq.

E-mail: simoschen@gmail.com

Jorge Manuel Nunes Ramos do Ó: Professor Associado com agregação do Instituto de Educação da Universidade de Lisboa. Tem trabalhado com temáticas relacionadas com história da educação e da cultura, educação artística, análise do discurso e pedagogia do ensino superior, em especial sobre os processos de escrita académica.

E-mail: jorge.o@ie.ulisboa.pt

Texto publicado em Currículo sem Fronteiras com autorização dos autores. 